\title{
MicroRNA Roles in the Nuclear Factor Kappa B Signaling Pathway in Cancer
}

\author{
Jin'en Wu't, Juntao Ding ${ }^{2 t}$, Jing Yang ${ }^{1}$, Xiaola Guo ${ }^{1}$ and Yadong Zheng ${ }^{1,3 *}$ \\ ${ }^{1}$ State Key Laboratory of Veterinary Etiological Biology, Key Laboratory of Veterinary Parasitology of Gansu Province, \\ Lanzhou Veterinary Research Institute (CAAS), Lanzhou, China, ${ }^{2}$ College of Life Science and Technology, Xinjiang University, \\ Urumqi, China, ${ }^{3}$ Jiangsu Co-innovation Center for Prevention and Control of Important Animal Infectious Diseases and \\ Zoonoses, College of Veterinary Medicine, Yangzhou University, Yangzhou, China
}

OPEN ACCESS

Edited by: Fabrizio Mattei, Istituto Superiore di Sanità, Italy

Reviewed by: Hector A. Cabrera-Fuentes, Justus Liebig Universität Gießen,

Germany

Roberto Bei,

Università degli Studi di Roma Tor Vergata, Italy

*Correspondence: Yadong Zheng zhengyadong@caas.cn

tThese authors have contributed equally to this work.

Specialty section: This article was submitted to Cancer Immunity and Immunotherapy,

a section of the journal

Frontiers in Immunology

Received: 29 December 2017 Accepted: 02 March 2018 Published: 19 March 2018

Citation:

Wu J, Ding J, Yang J, Guo $X$ and

Zheng Y (2018) MicroRNA Roles in the Nuclear Factor Kappa B Signaling

Pathway in Cancer.

Front. Immunol. 9:546.

doi: 10.3389/fimmu.2018.00546
Nuclear factor kappa B (NF-кB) is a pluripotent and crucial dimer transcription factor that orchestrates various physiological and pathological processes, especially cell proliferation, inflammation, and cancer development and progression. NF- $\mathrm{kB}$ expression is transient and tightly regulated in normal cells, but it is activated in cancer cells. Recently, numerous studies have demonstrated microRNAs (miRNAs) play a vital role in the NF-kB signaling pathway and NF-kB-associated immune responses, radioresistance and drug resistance of cancer, some acting as inhibitors and the others as activators. Although it is

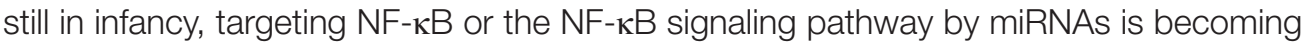
a promising strategy of cancer treatment.

Keywords: microRNAs, nuclear factor kappa B, cancer, molecular therapy, nuclear factor kappa B-associated resistance

\section{INTRODUCTION}

Tumorigenesis is the result of multistep interactions of multi-factors and -genes, and the mechanisms whereby the tumors occur need to be further explored. In recent years, cancer research has undergone a rapid development and achieved a major breakthrough. The 10 hallmarks that are involved in tumor growth and metastasis have been reported (1), and their complex progression ultimately induces incipient tumor cells to develop into tumorigenic and malignant cancer.

MicroRNAs (miRNAs), a class of endogenous and single-stranded RNA, are a subfamily of small non-coding regulatory RNA with a size of 18-22 nt, being involved in various physiological and pathological processes. Increasing studies have demonstrated that miRNAs play a significant role in tumorigenesis and progression, via directly or indirectly regulating the expression of various oncogenes or tumor suppressors (2-4). As a transcription factor, nuclear factor kappa B (NF- $\mathrm{KB}$ ) expression is transient and tightly regulated in normal cells, but it is highly activated in cancer cells (5). NF- $\mathrm{\kappa B}$ is not only involved in immune responses $(6,7)$, but it also plays an important role in the development and progression of tumor $(8,9)$, metastasis (10), and drug resistance (11). Recently, it has been demonstrated that miRNAs are involved in the regulation of NF- $\mathrm{KB}$ signaling pathway by different mechanisms (12-14). These interactions suggest that miRNAs and NF- $\mathrm{kB}$ can be used

Abbreviations: NF-кB, nuclear factor kappa B; HCC, hepatic cellular cancer; ATL, adult T cell leukemia/lymphoma; TAD, transcription activation domain; TNF, tumor necrosis factor; RHD, Rel homology domain; TLR, toll-like receptor; IL, interleukin; IRAK, interleukin-1 receptor-associated kinase; PEG3, paternally expressed gene 3; TAK, transforming growth factor$\beta$-activated kinase; SOCS, suppressor of cytokine signaling; TNIP, tumor necrosis factor alpha induced protein 3 interacting protein; CYLD, cylindromatosis. 
as potential tumor diagnostic biomarkers and drug therapeutic targets in clinical treatment of cancer.

\section{miRNA BIOGENESIS AND ITS EXPRESSION IN CANCER}

MicroRNAs are mainly transcribed by RNA polymerase II, and in the canonical pathway the resulting transcripts, known as primary miRNAs, are cleaved by Drosha-DGCR8 to produce precursor miRNAs (pre-miRNAs) that are exported to the cytoplasm by exportin-5 and Ran-GTP $(15,16)$. In the cytoplasm, pre-miRNAs are processed into miRNA duplexes by Dicer, and mature miRNAs are incorporated into the AGO2-containing small RNA-induced silencing complex, while the counterparts, known as miRNAs*, are degraded in most cases $(2,17,18)$. In addition to the canonical pathway, a small part of miRNAs are derived from introns and spliced by spliceosome in a Droshaindependent pathway (19). miRNAs can regulate mRNA stability or translation by interacting with binding site(s) in the $3^{\prime}$ untranslated region (UTR) of targets.

Increasing literatures have documented that miRNAs are implicated in the pathogenesis of various malignancies $(20,21)$, and they represent key players in cancer development and metastasis processes as well (22), such as thymic epithelial tumors
(23), renal cancer (24), colorectal cancer (25), and so on. It is undoubted that miRNA expression profiles are different in the distinct tumors, and a specific set of miRNAs are upregulated or downregulated in the specific tumor cells (4). Although the correlation between miRNA dysregulation and cancer has been demonstrated, it is still not clear whether changed expression of miRNAs promotes carcinogenesis or the development of cancer causes ectopic expression of miRNAs. Therefore, understanding the functions of miRNAs and their targets in the relevant signaling pathways is of great importance and may help us develop potential diagnosis and therapeutic approaches for cancer.

\section{NF-кB SIGNALING PATHWAY}

Nuclear factor kappa B is a transcription factor that presents in the cytoplasm of a cell and regulates the expression of immune and growth genes $(26,27)$. It is heterodimeric or homodimeric combinations of five different protein subunits, including RelA

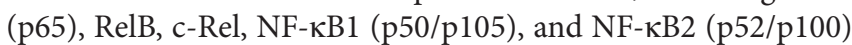
(Figures 1A,B), all of which commonly share a N-terminal Rel homology domain responsible for DNA binding and dimerization $(28,29)$. All 5 family members can potentially form 15 different homodimeric or heterodimeric complexes (30). The transcription activation domain (TAD) is necessary for gene expression,

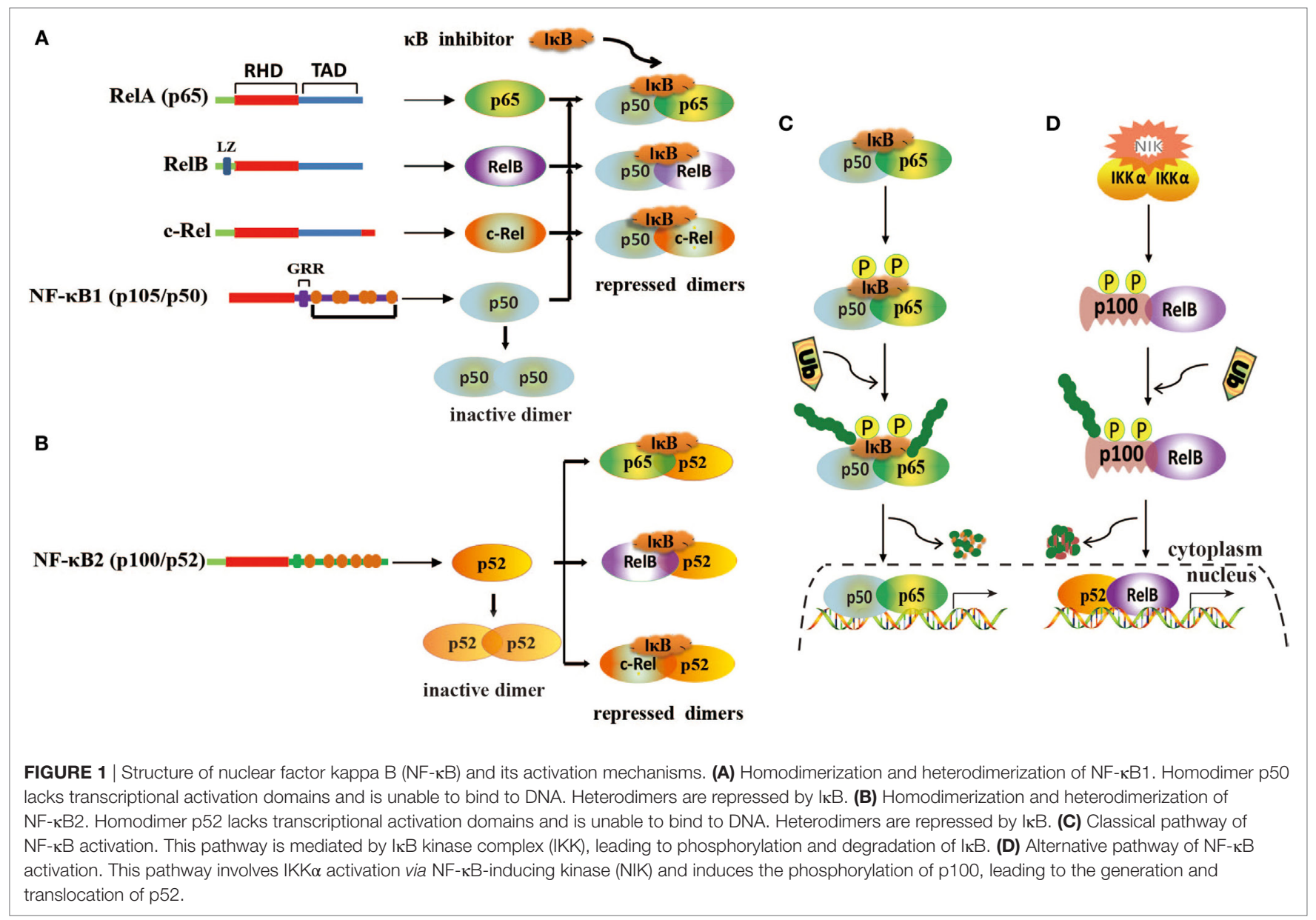


but both NF-kB1 (p50/p105) and NF-kB2 (p52/p100) lack TAD (31). Thus, p50 and p52 cannot activate gene expression unless they associate with a NF- $\kappa B$ family member containing TAD or recruit a specific coactivator (29). In resting cells, NF- $\mathrm{\kappa B}$ dimers are sequestered in the cytoplasm through combining inhibitory

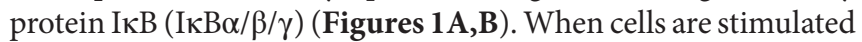
by various agents, such as bacteria, virus, cytokines, and tumor promoter, NF- $\mathrm{KB}$ is rapidly activated and translocated into the nuclear to promote the expression of genes by binding to $\mathrm{\kappa B}$ sites (32). Generally, NF- $\mathrm{kB}$ is activated by two signaling pathways, a classical pathway and an alternative pathway (33). In the classical pathway, NF- $\mathrm{KB}$ activation is precisely mediated through the phosphorylation and polyubiquitination of I $\kappa \mathrm{B}$ members and then degradation by proteasome (Figure 1C) (34). In the alternative pathway, p100 and p105 are processed and degraded to p52 and p50 by an IKB-independent pathway (Figure 1D) (35).

In normal cells, NF- $\mathrm{KB}$ is tightly controlled by regulating its

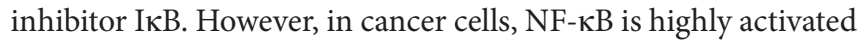
and translocated to the nucleus to induce cell proliferation and immortalization by dysregulation of various signaling pathways $(8,36)$. These processes are also regulated by miRNAs that modulate the NF- $\mathrm{\kappa B}$ signaling pathway.

\section{REGULATION OF NF- $\kappa B$ SIGNALING BY MIRNAS IN CANCER}

Nuclear factor kappa B is activated in various cancer types as an important inducible carcinogenesis mediator (37), making malignant tumor cells to evade apoptosis from cell cycle checkpoint (38). In recent years, increasing evidence has demonstrated that miRNAs and NF- $\mathrm{KB}$ play an important role in tumor development and progression $(6,39,40)$. Particularly, NF- $\mathrm{\kappa B}$ can be directly or indirectly activated by miRNAs in cancer cells or oncogenic human virus-infected cells (Table 1).

\section{NF-кB Activation by miRNAs in non-Viral Tumors}

Numerous pathways can induce the activation of NF- $\mathrm{kB}$ in different types of cancer. In addition, miRNAs also target the key components and regulatory proteins of the NF- $\mathrm{kB}$ signaling pathway to modulate the activity of NF- $\mathrm{kB}$, such as tumor necrosis factor (TNF), a secreted proinflammatory cytokine. For instance, significantly low expression of miR-9 promoted NF- $\kappa B 1$ overexpression, thus enhancing NF- $\kappa B$ activities and inducing ovarian cancer cell proliferation (57). In cervical cancer cells, upregulated miR-130a directly targeted the $3^{\prime}$ UTR of TNF- $\alpha$ and reduced its expression, and then downregulated TNF- $\alpha$-activated NF- $\kappa B$ activity and enhanced miR-130a expression by a negative feedback loop of NF- $\kappa \mathrm{B} / \mathrm{miR}-130 \mathrm{a} /$ TNF- $\alpha / N F-\kappa B(51)$.

\section{miRNAs Involved in the Regulation of Myeloid Differentiation Factor 88 (MyD88)}

Myeloid differentiation factor 88 is a critical adaptor protein in the toll-like receptor (TLR)/interleukin (IL)-1R receptor family

TABLE 1 | MicroRNAs (miRNAs) involved in the regulation of the nuclear factor kappa B (NF-kB) pathway in cancer.

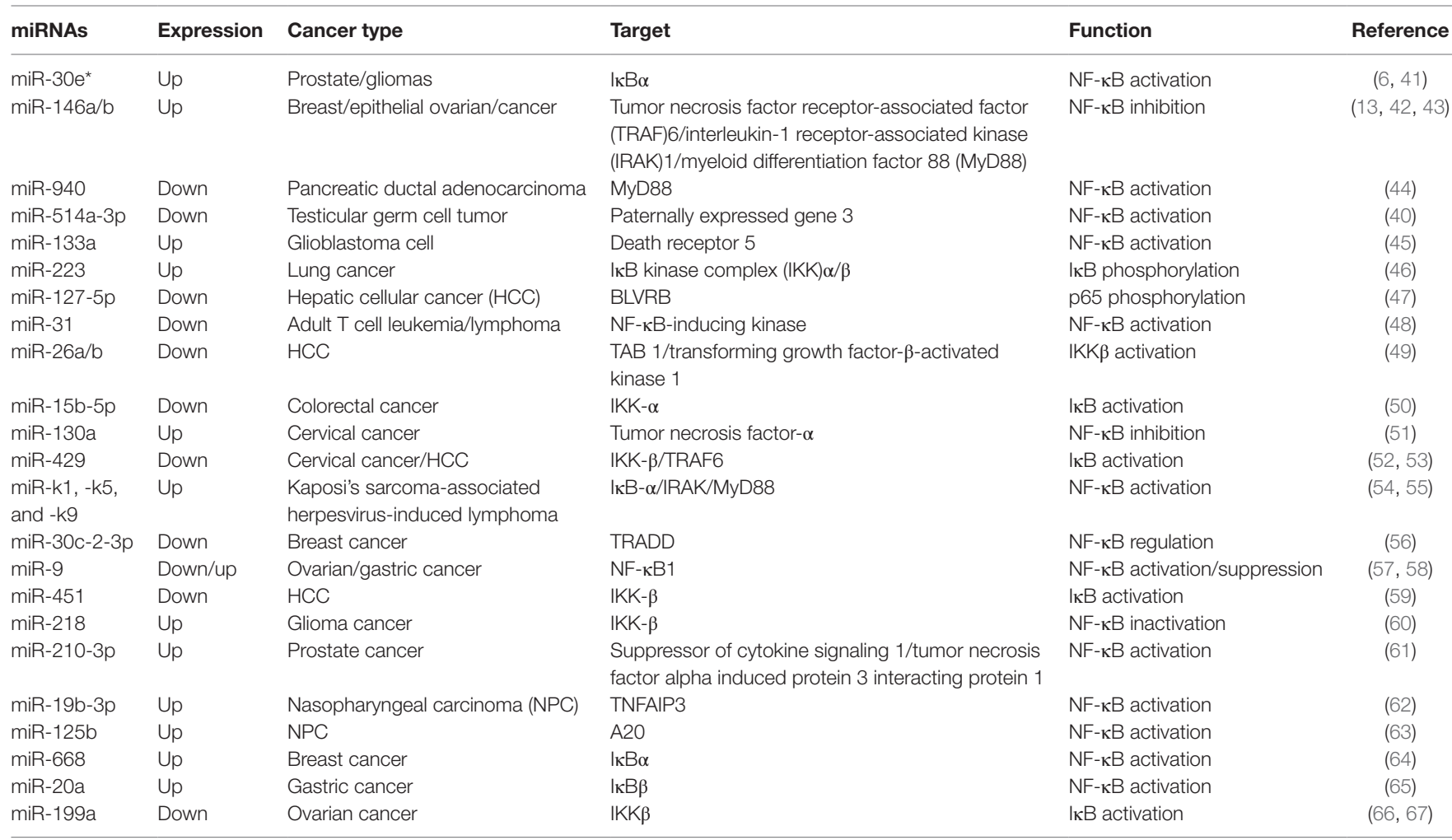


signaling pathway. It was reported that miR-940 targeted the 3' UTR of MyD88, being involved in the activation of NF- $\kappa B$ in pancreatic ductal adenocarcinoma (44). A low level of miR-940 led to an elevated expression of MyD88 and promoted pancreatic ductal adenocarcinoma cell growth. Furthermore, miR-146a was also shown to target and reduce MyD88 expression, thus inhibiting the NF- $\kappa \mathrm{B}$ activation in epithelial ovarian cancer, and directly regulating the sensitivity of ovarian cancer cells to drug therapy (42). Therefore, miRNAs can regulate NF- $\kappa \mathrm{B}$ activities by targeting MyD88, which has a very important significance for tumor development.

\section{miRNAs Involved in the Regulation of Tumor Necrosis Factor Receptor-Associated Factor (TRAF)} Tumor necrosis factor receptor-associated factors are a class of multi-functional intracellular signaling adaptor proteins, being involved in signal transduction of multiple receptor families, including apoptosis factor receptor family (TNFR), TLR family (68), interleukin-1 receptor family, NF- $\mathrm{BB}$ receptor activating factor family (RANK), and so on (Figure 2). TRAF interacts with downstream proteins in a cell and eventually initiates NF- $\mathrm{BB}$ activation through miRNAs. For example, miR-146a/b was identified as an inhibitor for TRAF6 and interleukin-1 receptor-associated kinase (IRAK) 1 in breast cancer cells MDA-MB-231 and downregulated TRAF6 eventually gave rise to the suppression of NF- $\kappa B$ activities (43). In human testicular germ cell tumor, loss of miR-514a-3p upregulated paternally expressed gene 3 (PEG3) and consequently overexpressed PEG3 recruited TRAF2 to activate the NF- $\kappa \mathrm{B}$ pathway (40). Moreover, it has been recently demonstrated that downregulated miR-429 markedly promoted proliferation and migration of hepatic cellular cancer (HCC) by targeting TRAF6 through the NF- $\mathrm{KB}$ pathway, while upregulation of miR-429 significantly suppressed HCC growth (52). Therefore, it is becoming clear that miR-146a/b, miR-514a-3p, and miR-429

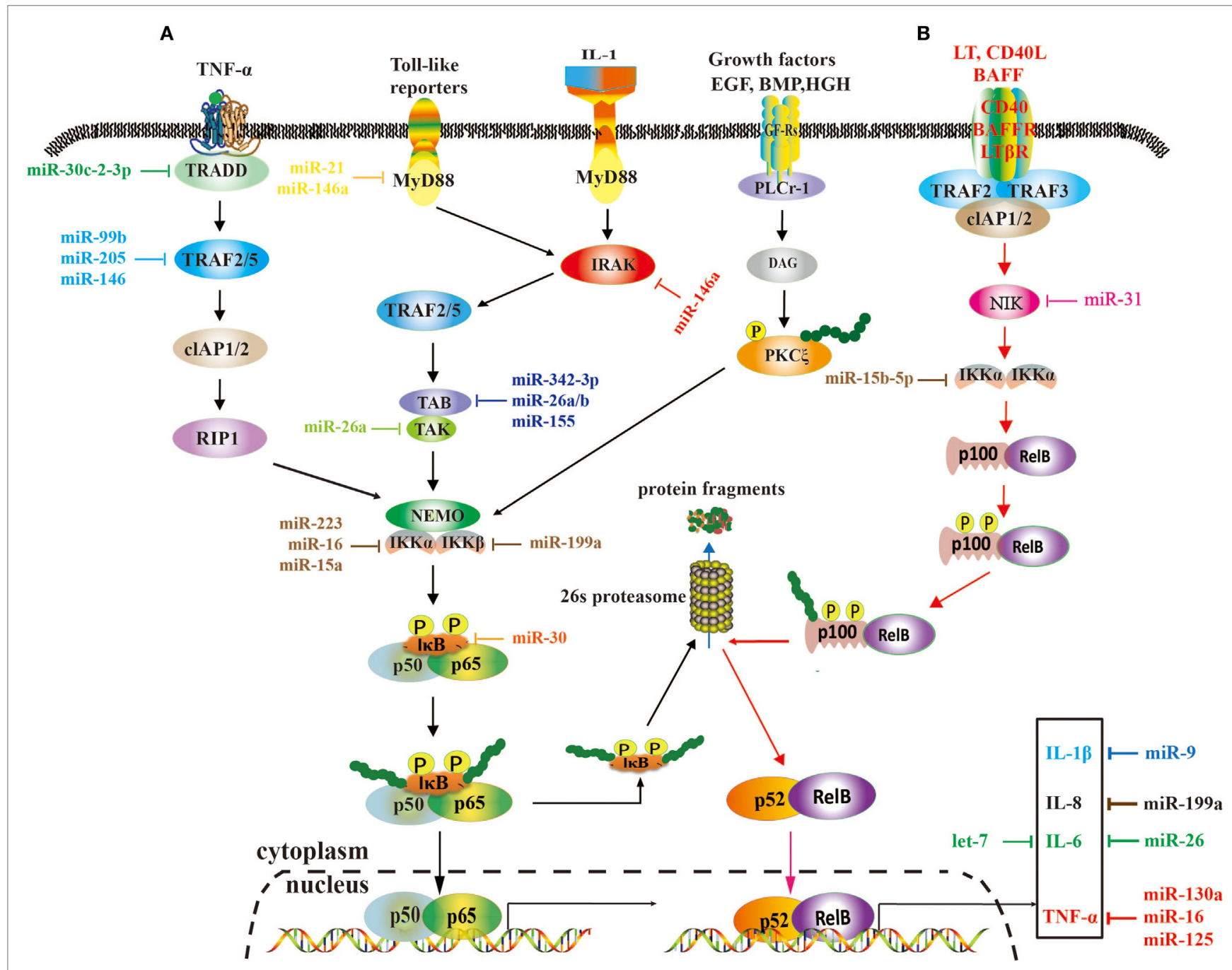

FIGURE 2 | A role of microRNAs (miRNAs) in the nuclear factor kappa B (NF-кB) signaling pathways. These two pathways rely on tumor necrosis factor (TNF), toll-like, interleukin (IL)-1, and EGF receptors (A), and BAFF reporter and CD40 (B), respectively, and they are activated or repressed by miRNAs. Activated NF-KB promotes or restrains the expression of tumor-associated genes. 
may serve as a potential target for the treatment of HCC via regulation of TRAF.

\section{miRNAs Involved in the Regulation of Transforming Growth Factor- $\beta$-Activated Kinase (TAK)1}

Transforming growth factor- $\beta$-activated kinase 1 is a serine/threonine protein kinase, which is activated by specifically binding to TAB 1-3 protein and ubiquitinated TRAF6, being involving in intracellular signal transduction, I $\beta$ activation, and NF- $\kappa \mathrm{B}$ cascade activation (69). Emerging evidence implies that miRNAs regulate TAK1 expression to promote tumorous invasion, metastasis, and chemoresistance. It was reported that miR-143 targeted TAK1 to attenuate development and progression of pancreatic ductal adenocarcinoma via NF- $\kappa$ B pathway (70). Similarly, miR-146a and miR-26b were also demonstrated to target TAK1 to promote gastric cancer cell apoptosis (71) and suppress the NF- $\kappa B$ signaling and enhance the chemosensitivity of HCC (49), respectively. These data suggest that miR-143, miR-146a, and miR-26b act as a potent inhibitor of the NF- $\kappa$ B pathway.

\section{miRNAs Involved in the Regulation of ІкB Kinase Complex (IKK)}

The IKK includes three kinase subunits, one being the regulatory subunit NEMO, also known as IKK $\gamma$, and the rest two being serine-threonine kinases (IKK $\alpha$ and IKK $\beta$ ). They are a signal integration hub for $\mathrm{I} \kappa \mathrm{B}$ phosphorylation and NF- $\kappa \mathrm{B}$ activation $(72,73)$. Recent studies have showed that abnormal expression of IKK promotes proliferation and invasive ability of cancer cells by miRNAs. miR-218 was able to downregulate IKK- $\beta$ expression and inactivated the NF- $\kappa \mathrm{B}$ signaling, leading to dramatic reduction of the migratory and invasive ability of glioma cells (60). In ovarian cancer, downregulated miR199 a, a regulator of IKK- $\beta$ expression, promoted a functional TLR-MyD88-NF- $\kappa$ B pathway and induced ovarian cancer cells to secret proinflammatory cytokines and enhance tumor progression (66). As a key tumor suppressor, miR-15b-5p was also markedly downregulated in colorectal cancer. It promoted $\mathrm{NF}-\kappa \mathrm{B}$ activation through negative regulation of IKK- $\alpha$ that induce I $\mathrm{B}$ phosphorylation (50). In HCC cells, markedly downregulated miR-451 promoted the tumorigenicity by direct targeting of IKK- $\beta$. On the contrary, upregulation of miR-451 resulted in downregulation of cyclin D1 and c-Myc through the inhibition of NF- $\mathrm{KB}$ pathway, thus decreasing proliferation of HCC cells (59).

\section{miRNAs Involved in the Regulation of $\mathbf{l \kappa} \mathrm{B}$ and Other NF-кB-Associated Components}

The activation of NF- $\kappa \mathrm{B}$ is universally achieved via first IкB phosphorylation by IKK $\beta$ and degradation by ubiquitination. In cervical cancer, the downregulated miR-429 elevated IKK $\beta$ expression and promoted NF- $\kappa \mathrm{B}$ activation by phosphorylating IкBs (53). Nevertheless, miR-30 $\mathrm{e}^{\star}$ was hyperexpressed in prostate cancer and targeted $\mathrm{I} \kappa \mathrm{B} \alpha(61)$, thus increasing free cytoplasmic NF- $\kappa \mathrm{B}$ to translocate into the nucleus to regulate the expression of cyclin D1 and consequently enhancing tumor proliferation and growth (6). Similarly, the expression of miR210-3p was also elevated in prostate cancer cells, particularly in bone-metastatic prostate cancer cells, and it was directly targeted multiple negative regulators of the NF- $\kappa \mathrm{B}$ signaling pathways, including suppressor of cytokine signaling 1 and tumor necrosis factor alpha induced protein 3 interacting protein 1, resulting in constitutive activation of the NF- $\mathrm{KB}$ signaling, and promoting EMT of bone-metastatic prostate cancer cells (61). In the lung cancer cells, overexpression of miR-223 was found to significantly promote tumor progression through activating NF- $\kappa \mathrm{B}$, but the mechanisms are still elusive (46). In gastric cancer, miR-20a directly targeted cylindromatosis and I $\mathrm{B} \beta$, promoting activation of the NF- $\kappa$ B pathway and its downstream targets, such as livin and survivin, which potentially induced chemoresistance $(65,74)$. Moreover, it was reported that overexpression of Polycomb regulated the non-canonical NF- $\kappa B$ pathway by inhibiting miR-31 to upregulate the NF- $\mathrm{KB}$-inducing kinase expression level in adult T cell lymphoma (48). In HCC, downregulated miR-127-5p induced the overexpression of BLVRB to promote NF- $\kappa \mathrm{B}$ activity and enhance HCC cell growth (47). Similarly, miR-30c-2-3p also acted as one of the strongest negative regulators and activated NF- $\mathrm{\kappa B}$ signaling through downregulation of TRADD in breast cancer (56).

In some cases, the NF- $\kappa \mathrm{B}$ signaling pathway can regulate the levels of miRNAs by controlling relative protein expression to participate in cancer occurrence (75). It has been reported that there are four NF- $\mathrm{BB}$-binding sites in the miR-130a gene promoter region and miR-130a is upregulated upon NF- $\kappa B$ binding, which leads to the downregulation of PTEN to promote cervical cancer cell growth (76). The ectopic expression of NF- $\kappa \mathrm{B}$ disturbs oncogenic miR-221 and miR-222 expression in prostate carcinoma and glioblastoma cell lines, possibly by NF- $\kappa \mathrm{B}$ binding to two sites in the upstream of miR-221/222 promoter (77).

\section{NF-kB Activation by miRNAs in Viral Tumors}

For some oncogenic viruses, their infections can activate the $\mathrm{NF}-\kappa \mathrm{B}$ signaling pathway by altering cellular endogenous miRNAs. High-risk human papillomavirus (HPV) infection leads to aberrant expression of tumor suppressive miRNAs of infected cells and oncogenicity. HPV E6 and E7 oncoproteins regulate the expression of miR-34a and miR-15a/miR-16-1 via degrading tumor suppressor proteins such as p53 and pRB, respectively (78). As a transcription factor, p53 is directly degraded by E6 oncoprotein, which binds to a p53-binding site in the miR-34a promoter region and mediates its expression (79). E7 oncoprotein releases E2F from the pRB-E2F complex and degrades tumor suppressor $\mathrm{pRB}(80)$. Free E2F binds to the promoter regions and regulates the expression of $\mathrm{miR}-15 \mathrm{a} / \mathrm{miR}-16-1$ and $\mathrm{miR}-106 \mathrm{~b}-25$ (81). Moreover, several studies have reported that the expression of HPV early protein E1, a viral helicase, activates DNA damage response pathways. Its key regulator, ataxia telangiectasia mutated, has a function in reduction of $\mathrm{I} \kappa \mathrm{B} \alpha$ by phosphorylation and activation of the NF- $\kappa \mathrm{B}$ signaling pathway (82). Afterward, the activated NF- $\mathrm{KB}$ binding to the miR-221 promoter region induces its overexpression (83). It is likely that the infection by high-risk types of HPV causes aberrant cellular miRNA expression and then promotes the formation of cervical cancer (78). In 
addition, upregulation of miR-221 also promotes HCV infection in a NF- $\kappa \mathrm{B}$-dependent manner in HCV-associated HCC (84).

In the other hand, viral miRNAs can also regulate immunoreactions through targeting the NF- $\mathrm{BB}$ signaling pathway. Kaposi's sarcoma-associated herpesvirus miR-k9 and miR-k5 regulated NF- $\mathrm{KB}$ activation by targeting IRAK and MyD88 to repress IL-6 and IL-8 expression and enhance viral infection (54). On the contrary, miR-k1 directly repressed the expression of $\mathrm{I} \kappa \mathrm{Ba}$, enhanced the transcriptional activities of NF- $\mathrm{BB}$, and inhibited viral lytic replication (55). However, these studies on the interactions between viral miRNAs and intracellular NF- $\kappa \mathrm{B}$ are still seriously inadequate. Therefore, uncovering NF- $\kappa \mathrm{B}$ functions via elucidating molecular mechanisms underlying a role of miRNAs in the persistence and pathogenesis of viral infection-induced cancer is extremely important.

\section{NF- $\kappa B-A S S O C I A T E D$ RESISTANCE IN CANCER AND miRNAs-TARGETING THERAPY}

Chemotherapy, radiotherapy, and targeted therapy are the effective ways for the treatment of tumors, but drug- and radioresistance inevitably limits therapeutic effects of long term (85, 86). Recently, growing evidence has shown that NF- $\kappa$ B is not only involved in the development and progression of cancer but also exerts the main function in modulating antitumor immunity $(87,88)$. Meanwhile, it has been reported that the NF- $\kappa B$ signaling pathway can be activated by most chemotherapeutic agents and radiation therapy, and may be a causative factor for drug resistance (89-91). Even for some cancer cells, transient exposure to a low-dose of doxorubicin could enhance drug resistance via activation of the NF- $\mathrm{BB}$ signaling pathway (92). TRAIL is a promising specifically targeted anticancer agent, but it can stimulate the activation of NF- $\kappa \mathrm{B}$ to promote the proliferation of cancer cells (93). Moreover, TRAIL activates a positive feedback loop that sustains the acquired drug resistance by inducing NF- $\kappa \mathrm{B}-$ dependent overexpression of miR-21 and miR-100, which both target TRAF7 to further activate the NF- $\kappa B$ signaling $(39,94)$. Recently, miR-133a was found to be upregulated in the human glioblastoma cell lines M059J and M059K, and it strongly promoted TRAIL resistance by suppressing death receptor 5 expression and activating NF- $\kappa B$ signaling (45). For nasopharyngeal carcinoma (NPC), radiotherapy is the primary treatment strategy, but significantly upregulated miR-19b-3p decreases NPC radiosensitivity by targeting TNFAIP3 to increase NF- $\kappa B$ activity (62). Meanwhile, miR-125b was also found to enhance radioresistance through targeting $\mathrm{A} 20$ and then activating the $\mathrm{NF}-\kappa \mathrm{B}$ in NPC (63). Another example for radioresistance is miR- 668 that directly targets the NF- $\kappa B$ inhibitor $I \kappa B \alpha$ to activate $\mathrm{NF}-\kappa \mathrm{B}$, and then enhances radioresistance of human breast cancer MCF-7 and T-47D cells (64). Thus, combinatory treatment using anticancer chemotherapy drug and NF- $\mathrm{\kappa B}$ inhibitors could revert drug resistance and reduce tumor growth.

Activation of NF- $\kappa \mathrm{B}$ affects the transcription of over 400 genes and promotes cells to involve antiapoptotic responses, metastases and drug resistance $(28,95,96)$. Targeting NF- $\kappa B$ or the NF- $\kappa B$ signaling pathway by miRNAs will be a promising strategy for the treatment of cancer. For the overexpressed miRNAs regulating the NF- $\kappa$ B signaling, antagonists (anti-miR or antagomiR or antisense oligonucleotides) and modified chemically antisense oligonucleotides against corresponding miRNAs are effective tools to decrease the expression levels of endogenous miRNAs. Antagonists have been demonstrated with a strong potential to effectively downregulate targeted miRNAs in cancer (97). An inhibitor of miR-223, one of the highly expressed miRNAs in lung cancer cells, significantly decreased cell viability and invasion by repressing the expression levels of IKK $\alpha / \beta$ and NF- $\kappa B$ (46). Overexpression of miR-21, an antionco-miRNA, effectively reduced the proliferation and migration of human colon carcinoma cells. Further studies revealed that elevated miR-21 reduced the phosphorylation of ERK1/2 (98). As phosphorylated ERK1/2 is associated with NF- $\mathrm{KB}$ in the nucleus, it is supposed that the NF- $\kappa B$ activity will be decreased in the treated cells. In a diametrically opposite approach, miRNA mimics, a class of artificially synthetic miRNAs, are applied to restore loss of function of miRNAs in cancer cells (99). For example, miR-520b mimics sharply reduced breast cancer cell migration by targeting HBXIP and IL-8 via a network, in which HBXIP accelerates cell migration by activating NF- $\mathrm{BB}$-mediated IL-8 expression (100). In ovarian carcinoma cells, the transfection with miR-141 mimics was able to inhibit KEAP1, which can bind to IKK $\beta$ to activate the $\mathrm{NF}-\kappa \mathrm{B}$ signaling pathway, and then enhanced resistance to cisplatin (101). Another therapeutic method is the "miRNA sponge effects." It refers to robust overexpression of artificial small RNAs using viral vectors such as lentiviruses or adenoviruses encoding miRNA mimics or antagonists, which restore the loss of miRNAs or decrease endogenous miRNAs $(102,103)$.

It is known that the first miRNA mimics MRX34 has already entered at the clinical treatment phase for the treatment of human pancreatic cancer in 2013 (85). Moreover, both miR$200 \mathrm{c}$ EDV s vectors and miR-29b mimics are also at a preclinical stage, and the results have shown that miR-200c enhances radiosensitivity (104) and miR-29b mimics by cationic lipoplexes transfection significantly inhibits tumor growth (105), but their possible long-term side effects should be further analyzed. Therefore, targeting NF- $\mathrm{KB}$ might not only directly decrease cancer invasiveness and metastases but also restore tumor cell sensitivity to chemotherapy and radiotherapy. Although miRNAs-targeting therapy attracts more and more attention, dose-dependent toxicity, off-target regulation, biosafety, and so on are still big challenges that need to be solved in the next few years.

\section{PERSPECTIVES}

As important transcriptional regulators, miRNAs can upregulate or downregulate many target genes involved in the NF-кB signaling pathway via negative or positive feedback loops, which are responsible for cancer initiation, development, progression, metastasis, and drug resistance. Therefore, miRNAs have been applied as molecular therapy targets, diagnosis markers, and prognostic indicators for cancer. Restoration or repression of miRNA expression levels has been showed a high potential for 
tumor therapy in cells and animal models. However, the clinical applications of miRNAs are greatly limited due to the multitarget, off-target, and instability. Therefore, further studies will be required to confirm the prognostic side effects of miRNA mimics and antagonists.

Furthermore, based on the current knowledge, many studies have just focused narrowly on the specific effects of a given miRNA targeting a specific mRNA by bioinformatic prediction algorithms, rather than exploring the "bigger picture" of gene expression regulation. With the depiction of this "bigger picture," it is expected that NF- $\mathrm{kB}$-targeting miRNAs are a promising potential target for various cancer treatment.

\section{REFERENCES}

1. Hanahan D, Weinberg RA. Hallmarks of cancer: the next generation. Cell (2011) 144(5):646-74. doi:10.1016/j.cell.2011.02.013

2. Hayes J, Peruzzi PP, Lawler S. MicroRNAs in cancer: biomarkers, functions and therapy. Trends Mol Med (2014) 20(8):460-9. doi:10.1016/j. molmed.2014.06.005

3. Reddy KB. MicroRNA (miRNA) in cancer. Cancer Cell Int (2015) 15:38. doi:10.1186/s12935-015-0185-1

4. Di Leva G, Garofalo M, Croce CM. MicroRNAs in cancer. Annu Rev Pathol (2014) 9:287-314. doi:10.1146/annurev-pathol-012513-104715

5. Dhawan P, Singh AB, Ellis DL, Richmond A. Constitutive activation of Akt/ protein kinase $\mathrm{B}$ in melanoma leads to up-regulation of nuclear factorkappaB and tumor progression. Cancer Res (2002) 62(24):7335-42.

6. Egan SM, Karasik E, Ellis L, Gollnick SO. miR-30 $\mathrm{e}^{\star}$ is overexpressed in prostate cancer and promotes NF-kB-mediated proliferation and tumor growth. Oncotarget (2017) 8(40):67626-38. doi:10.18632/oncotarget.18795

7. Matthew S, Hayden SG. NF-KB in immunobiology. Cell Res (2011) 21:223-44. doi:10.1038/cr.2011.13

8. Karim M. NF-kB as a critical link between inflammation and cancer. Cold Spring Harb Perspect Biol (2009) 1:a000141. doi:10.1101/cshperspect.a000141

9. Hoesel B, Schmid JA. The complexity of NF-KB signaling in inflammation and cancer. Mol Cancer (2013) 12:86. doi:10.1186/1476-4598-12-86

10. Huber MA, Azoitei N, Baumann B, Grünert S, Sommer A, Pehamberger H, et al. NF- $\mathrm{\kappa B}$ is essential for epithelial-mesenchymal transition and metastasis in a model of breast cancer progression. J Clin Invest (2004) 114:569-81. doi:10.1172/JCI200421358

11. Seubwai W, Vaeteewoottacharn K, Kraiklang R, Umezawa K, Okada S, Wongkham S. Inhibition of NF-kappaB activity enhances sensitivity to anticancer drugs in cholangiocarcinoma cells. Oncol Res (2016) 23(1-2):21-8. doi:10.3727/096504015X14424348426071

12. Ma X, Becker Buscaglia LE, Barker JR, Li Y. MicroRNAs in NF-kB signaling. J Mol Cell Biol (2011) 3:159-66. doi:10.1093/jmcb/mjr007

13. YANG Y, Wank JK. The functional analysis of microRNAs involved in NF- $\mathrm{kB}$ signaling. Eur Rev Med Pharmacol Sci (2016) 20:1764-74.

14. Sirotkin AV, Alexa R, Kišová G, Harrath AH, Alwasel S, Ovcharenko D, et al. MicroRNAs control transcription factor NF-kB (p65) expression in human ovarian cells. Funct Integr Genomics (2015) 15(3):271-5. doi:10.1007/ s10142-014-0413-0

15. Lund E, Güttinger S, Calado A, Dahlberg JE, Kutay U. Nuclear export of microRNA precursors. Science (2004) 303:95-8. doi:10.1126/science.1090599

16. Cai X, Hagedorn $\mathrm{CH}$, Cullen BR. Human microRNAs are processed from capped, polyadenylated transcripts that can also function as mRNAs. RNA (2004) 10:1957-66. doi:10.1261/rna.7135204

17. Gregory R, Chendrimada TP, Cooch N, Shiekhattar R. Human RISC couples microRNA biogenesis and posttranscriptional gene silencing. Cell (2005) 123:631-40. doi:10.1016/j.cell.2005.10.022

18. Ha M, Kim VN. Regulation of microRNA biogenesis. Nat Rev Mol Cell Biol (2014) 15(8):509-24. doi:10.1038/nrm3838

19. Kim VN, Han J, Siom MC. Biogenesis of small RNAs in animals. Nat Rev Mol Cell Biol (2009) 10:126-39. doi:10.1038/nrm2632

20. Adams BD, Kasinski AL, Slack FJ. Aberrant regulation and function of microRNAs in cancer. Curr Biol (2014) 24(16):R762-76. doi:10.1016/j.cub.2014.06.043

\section{AUTHOR CONTRIBUTIONS}

YZ conceived the study; JW, JD, JY, and XG analyzed the data; JW and $\mathrm{YZ}$ wrote the paper.

\section{FUNDING}

This work was financially supported by the National Natural Science Foundation of China (31472185, U1703104, and 31201900), the National Key Basic Research Program (973 program) of China (2015CB150300), and State Public-interest Institution Basal Research Fund (1610312016017).

21. Hata A, Lieberman J. Dysregulation of microRNA biogenesis and gene silencing in cancer. Sci Signal (2015) 8(368):re3. doi:10.1126/scisignal.2005825

22. Bouyssou JM, Manier S, Huynh D, Issa S, Roccaro AM, Ghobrial IM. Regulation of microRNAs in cancer metastasis. Biochim Biophys Acta (2014) 1845(2):255-65. doi:10.1016/j.bbcan.2014.02.002

23. Ganci F, Vico C, Korita E, Sacconi A, Gallo E, Mori F, et al. MicroRNA expression profiling of thymic epithelial tumors. Lung Cancer (2014) 85(2):197-204. doi:10.1016/j.lungcan.2014.04.008

24. Heinzelmann J, Hoelters S, Schneeweiss R, Stolzenbach F, Baumgart S, Gajda M, et al. MicroRNAs as regulators of cellular processes in distant metastases of renal cancer. Eur Urol Suppl (2014) 14(2):e860. doi:10.1016/ S1569-9056(15)60848-X

25. Neerincx M, Sie DL, van de Wiel MA, van Grieken NC, Burggraaf JD, Dekker $\mathrm{H}$, et al. miR expression profiles of paired primary colorectal cancer and metastases by next-generation sequencing. Oncogenesis (2015) 4:e170. doi:10.1038/oncsis.2015.29

26. Liang Y, Zhou Y, Shen P. NF- $\mathrm{KB}$ and its regulation on the immune system. Cell Mol Immunol (2004) 1(5):343-50.

27. Pikarsky E, Porat RM, Stein I, Abramovitch R, Amit S, Kasem S, et al. NF-kappaB functions as a tumour promoter in inflammation-associated cancer. Nature (2004) 431(7007):461-6. doi:10.1038/nature02924

28. Mamatha RS, Shanmuga RC. Function of nuclear factor kappa B (NF-kB) in human diseases-a review. South Ind J Biol Sci (2016) 2(4):368-87.

29. Hayden MS, Ghosh S. Shared principles in NF-kappaB signaling. Cell (2008) 132(3):344-62. doi:10.1016/j.cell.2008.01.020

30. Hoffmann A, Baltimore D. Circuitry of nuclear factor kappaB signaling. Immunol Rev (2006) 210:171-86. doi:10.1111/j.0105-2896.2006.00375.x

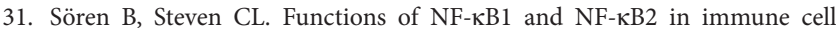
biology. Biochem J (2004) 382:393-409. doi:10.1042/BJ20040544

32. Ghosh S, May MJ, Kopp EB. NF-kappa B and Rel proteins: evolutionarily conserved mediators of immune responses. Annu Rev Immunol (1998) 16:225-60. doi:10.1146/annurev.immunol.16.1.225

33. Pereira SG, Oakley F. Nuclear factor-kappaB1: regulation and function. Int J Biochem Cell Biol (2008) 40(8):1425-30. doi:10.1016/j.biocel.2007.05.004

34. Hayden MS, Ghosh S. Signaling to NF-kB. Genes Dev (2002) 18(1):2195-224. doi:10.1101/gad.1228704

35. Sun SC, Ley SC. New insights into NF-kappaB regulation and function. Trends Immunol (2008) 29(10):469-78. doi:10.1016/j.it.2008.07.003

36. Naugler WE, Karin M. NF- $\mathrm{kB}$ and cancer-identifying targets and mechanisms. Curr Opin Genet Dev (2008) 18(1):19-26. doi:10.1016/j.gde.2008.01.020

37. Stahlhut C, Slack FJ. MicroRNAs and the cancer phenotype: profiling, signatures and clinical implications. Genome Med (2013) 5(12):111. doi:10.1186/ gm516

38. Kaltschmidt B, Kaltschmidt C, Hehner SP, Droge W, Schmitz ML. Repression of NF-kappaB impairs HeLa cell proliferation by functional interference with cell cycle checkpoint regulators. Oncogene (1999) 18(21):3213-25. doi:10.1038/sj.onc. 1202657

39. Jeon YJ, Middleton J, Kim T, Laganà A, Piovan C, Secchiero P. A set of NF-кBregulated microRNAs induces acquired TRAIL resistance in lung cancer. Proc Natl Acad Sci U S A (2017) 114:etal. doi:10.1073/pnas.170179511410.1073/ pnas. 1504630112

40. Ozata DM, Li X, Lee L, Liu J, Warsito D, Hajeri P, et al. Loss of miR514a-3p regulation of PEG3 activates the NF-kappa B pathway in human 
testicular germ cell tumors. Cell Death Dis (2017) 8(5):e2759. doi:10.1038/ cddis. 2016.464

41. Jiang L, Lin C, Song L, Wu J, Chen B, Ying Z, et al. MicroRNA-30e* promotes human glioma cell invasiveness in an orthotopic xenotransplantation model by disrupting the NF-kappaB/IkappaBalpha negative feedback loop. J Clin Invest (2012) 122(1):33-47. doi:10.1172/JCI58849

42. d'Adhemar CJ, Spillane CD, Gallagher MF, Bates M, Costello KM, BarryO'Crowley J, et al. The MyD88+ phenotype is an adverse prognostic factor in epithelial ovarian cancer. PLoS One (2014) 9(6):e100816. doi:10.1371/ journal.pone. 0100816

43. Bhaumik D, Scott GK, Schokrpur S, Patil CK, Campisi J, Benz CC. Expression of microRNA-146 suppresses NF-kappaB activity with reduction of metastatic potential in breast cancer cells. Oncogene (2008) 27(42):5643-7. doi:10.1038/onc.2008.171

44. Songa B, Zhangb C, Lia G, Jina G, Liuc C. miR-940 inhibited pancreatic ductal adenocarcinoma growth by targeting MyD88. Cell Physiol Biochem (2015) 35:1167-77. doi:10.1159/000373941

45. Wang S-S, Feng L, Hu B-G, Lu Y-F, Wang W-M, Guo W, et al. miR-133a promotes TRAIL resistance in glioblastoma via suppressing death receptor 5 and activating NF-kB signaling. Mol Ther Nucleic Acids (2017) 8:482-92. doi:10.1016/j.omtn.2017.07.015

46. Huang L, Li F, Deng P, Hu C. MicroRNA-223 promotes tumor progression in lung cancer A549 cells via activation of the NF-kappaB signaling pathway. Oncol Res (2016) 24(6):405-13. doi:10.3727/096504016X14685034103437

47. Huan L, Bao C, Chen D, Li Y, Lian J, Ding J, et al. MicroRNA-127-5p targets the biliverdin reductase $\mathrm{B} /$ nuclear factor-kappaB pathway to suppress cell growth in hepatocellular carcinoma cells. Cancer Sci (2016) 107(3):258-66. doi:10.1111/cas. 12869

48. Uribesalgo I, Ballaré C, Di Croce L. Polycomb regulates NF- $\mathrm{kB}$ signaling in cancer through miRNA. Cancer Cell (2012) 21(1):5-7. doi:10.1016/j. ccr.2011.12.019

49. Zhao N, Wang R, Zhou L, Zhu Y, Gong J, Zhuang SM. MicroRNA-26b suppresses the NF- $\mathrm{kB}$ signaling and enhances the chemosensitivity of hepatocellular carcinoma cells by targeting TAK1 and TAB 3. Mol Cancer (2014) 13:35. doi:10.1186/1476-4598-13-35

50. Zhao C, Zhao Q, Zhang C, Wang G, Yao Y, Huang X, et al. miR-15b-5p resensitizes colon cancer cells to 5 -fluorouracil by promoting apoptosis via the NF-kappaB/XIAP axis. Sci Rep (2017) 7(1):4194. doi:10.1038/ s41598-017-04172-z

51. Zhang J, Wu H, Li P, Zhao Y, Liu M, Tang H. NF-kB-modulated miR-130a targets TNF- $\alpha$ in cervical cancer cells. J Transl Med (2014) 12(155):1-14. doi:10.1186/1479-5876-12-155

52. Wang P, Cao J, Liu S, Pan H, Liu X, Sui A, et al. Upregulated microRNA-429 inhibits the migration of HCC cells by targeting TRAF6 through the NF-KB pathway. Oncol Rep (2017) 37(5):2883-90. doi:10.3892/or.2017.5507

53. Fan JY, Fan YJ, Wang XL, Xie H, Gao HJ, Zhang Y, et al. miR-429 is involved in regulation of NF-kappaB activity by targeting IKKbeta and suppresses oncogenic activity in cervical cancer cells. FEBS Lett (2017) 591(1):118-28. doi:10.1002/1873-3468.12502

54. Abend JR, Ramalingam D, Kieffer-Kwon P, Uldrick TS, Yarchoan R, Ziegelbauer JM. Kaposi's sarcoma-associated herpesvirus microRNAs target IRAK1 and MYD88, two components of the toll-like receptor/interleukin-1R signaling cascade, to reduce inflammatory-cytokine expression. $J$ Virol (2012) 86(21):11663-74. doi:10.1128/JVI.01147-12

55. Lei X, Bai Z, Ye F, Xie J, Kim C-G, Huang Y, et al. Regulation of NF-אB inhibitor IкB $\alpha$ and viral replication by a KSHV microRNA. Nat Cell Biol (2010) 12(2):193-9. doi:10.1038/ncb2019

56. Shukla K, Sharma AK, Ward A, Will R, Hielscher T, Balwierz A, et al. MicroRNA-30c-2-3p negatively regulates NF-kB signaling and cell cycle progression through downregulation of TRADD and CCNE1 in breast cancer. Mol Oncol (2015) 9(6):1106-19. doi:10.1016/j.molonc.2015. 01.008

57. Guo LM, Pu Y, Han Z, Liu T, Li YX, Liu M, et al. MicroRNA-9 inhibits ovarian cancer cell growth through regulation of NF-kappaB1. FEBS J (2009) 276(19):5537-46. doi:10.1111/j.1742-4658.2009.07237.x

58. Wan HY, Guo LM, Liu T, Liu M, Li X, Tang H. Regulation of the transcription factor NF-kappaB1 by microRNA-9 in human gastric adenocarcinoma. Mol Cancer (2010) 9:16. doi:10.1186/1476-4598-9-16
59. Li HP, Zeng XC, Zhang B, Long JT, Zhou B, Tan GS. miR-451 inhibits cell proliferation in human hepatocellular carcinoma through direct suppression of IKK- $\beta$. Carcinogensis (2013) 34(11):2443-51. doi:10.1093/carcin/bgt206

60. Song L, Huang Q, Chen K, Liu L, Lin C, Dai T, et al. miR-218 inhibits the invasive ability of glioma cells by direct downregulation of IKK- $\beta$. Biochem Biophys Res Commun (2010) 402(1):135-40. doi:10.1016/j.bbrc.2010.10.003

61. Ren D, Yang Q, Dai Y, Guo W, Du H, Song L, et al. Oncogenic miR-210-3p promotes prostate cancer cell EMT and bone metastasis via NF-kappaB signaling pathway. Mol Cancer (2017) 16(1):117. doi:10.1186/s12943-0170688-6

62. Huang T, Yin L, Wu J, Gu JJ, Wu JZ, Chen D. MicroRNA-19b-3p regulates nasopharyngeal carcinoma radiosensitivity by targeting TNFAIP3/ NF-kB axis. J Exp Clin Cancer Res (2016) 35(1):188. doi:10.1186/s13046016-0465-1

63. Li LN, Xiao T, Yi HM, Zheng Z, Qu JQ, Huang W, et al. miR-125b increases nasopharyngeal carcinoma radioresistance by targeting A20/NF- $\mathrm{\kappa B}$ signaling pathway. Mol Cancer Ther (2017) 16(10):2094-106. doi:10.1158/1535-7163. MCT-17-0385

64. Luo M, Ding L, Li Q, Yao H. miR-668 enhances the radioresistance of human breast cancer cell by targeting IkappaBalpha. Breast Cancer (2017) 24(5):673-82. doi:10.1007/s12282-017-0756-1

65. Du Y, Zhu M, Zhou X, Huang Z, Zhu J, Xu J, et al. miR-20a enhances cisplatin resistance of human gastric cancer cell line by targeting NFKBIB. Tumour Biol (2016) 37(1):1261-9. doi:10.1007/s13277-015-3921-1

66. Chen R, Alvero AB, Silasi DA, Kelly MG, Fest S, Visintin I, et al. Regulation of IKKbeta by miR-199a affects NF-kappaB activity in ovarian cancer cells. Oncogene (2008) 27(34):4712-23. doi:10.1038/onc.2008.112

67. Dai L, Gu L, Di W. miR-199a attenuates endometrial stromal cell invasiveness through suppression of the IKKbeta/NF-kappaB pathway and reduced interleukin-8 expression. Mol Hum Reprod (2012) 18(3):136-45. doi:10.1093/ molehr/gar066

68. Kawai T, Akira S. Signaling to NF-kappaB by toll-like receptors. Trends Mol $\operatorname{Med}$ (2007) 13(11):460-9. doi:10.1016/j.molmed.2007.09.002

69. Fan Y, Yu Y, Shi Y, Sun W, Xie M, Ge N, et al. Lysine 63-linked polyubiquitination of TAK1 at lysine 158 is required for tumor necrosis factor alpha- and interleukin-1beta-induced IKK/NF-kappaB and JNK/AP-1 activation. J Biol Chem (2010) 285(8):5347-60. doi:10.1074/jbc.M109.076976

70. Huang FT, Peng JF, Cheng WJ, Zhuang YY, Wang LY, Li CQ, et al. miR-143 targeting TAK1 attenuates pancreatic ductal adenocarcinoma progression via MAPK and NF-kB pathway in vitro. Dig Dis Sci (2017) 62(4):944-57. doi:10.1007/s10620-017-4472-7

71. Chen Y, Zhou B, Xu L, Fan H, Xie J, Wang D. MicroRNA-146a promotes gastric cancer cell apoptosis by targeting transforming growth factor $\beta$-activated kinase 1. Mol Med Rep (2017) 16(1):755-63. doi:10.3892/mmr.2017.6640

72. Mercurio F, Zhu H, Murray BW, Shevchenko A, Bennett BL, Li J. IKK-1 and

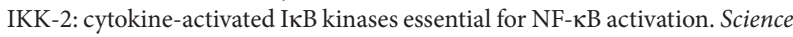
(1997) 278(5339):860-6. doi:10.1126/science.278.5339.860

73. Zandi E, Rothwarf DM, Delhase M, Hayakawa M, Karin M. The IкB kinase complex (IKK) contains two kinase subunits, IKK $\alpha$ and IKK $\beta$, necessary for IאB phosphorylation and NF-KB activation. Cell (1997) 91(2):243-52. doi:10.1016/S0092-8674(00)80406-7

74. Zhu M, Zhou X, Du Y, Huang Z, Zhu J, Xu J, et al. miR-20a induces cisplatin resistance of a human gastric cancer cell line via targeting CYLD. Mol Med Rep (2016) 14(2):1742-50. doi:10.3892/mmr.2016.5413

75. Hai Ping P, Feng Bo T, Li L, Nan Hui Y, Hong Z. IL-1beta/NF-kb signaling promotes colorectal cancer cell growth through miR-181a/PTEN axis. Arch Biochem Biophys (2016) 604:20-6. doi:10.1016/j.abb.2016.06.001

76. Feng Y, Zhou S, Li G, Hu C, Zou W, Zhang H, et al. Nuclear factorkappaB-dependent microRNA-130a upregulation promotes cervical cancer cell growth by targeting phosphatase and tensin homolog. Arch Biochem Biophys (2016) 598:57-65. doi:10.1016/j.abb.2016.03.019

77. Galardi S, Mercatelli N, Farace MG, Ciafre SA. NF-kB and c-Jun induce the expression of the oncogenic miR-221 and miR-222 in prostate carcinoma and glioblastoma cells. Nucleic Acids Res (2011) 39(9):3892-902. doi:10.1093/ nar/gkr006

78. Zheng ZM, Wang X. Regulation of cellular miRNA expression by human papillomaviruses. Biochim Biophys Acta (2011) 1809(11-12):668-77. doi:10.1016/ j.bbagrm.2011.05.005 
79. Chang TC, Wentzel EA, Kent OA, Ramachandran K, Mullendore M, Lee KH, et al. Transactivation of miR-34a by p53 broadly influences gene expression and promotes apoptosis. Mol Cell (2007) 26(5):745-52. doi:10.1016/j.molcel. 2007.05.010

80. Gonzalez SL, Stremlau M, He X, Basile JR, Munger K. Degradation of the retinoblastoma tumor suppressor by the human papillomavirus type 16 E7 oncoprotein is important for functional inactivation and is separable from proteasomal degradation of E7. J Virol (2001) 75:7583-91. doi:10.1128/ JVI.75.16.7583-7591.2001

81. Bueno MJ, de Cedrón GM, Laresgoiti U, Fernandez PJ, Zubiaga AM, Malumbres M. Multiple E2F-induced microRNAs prevent replicative stress in response to mitogenic signaling. Mol Cell Biol (2010) 30:2983-95. doi:10.1128/MCB.01372-09

82. Nakahara T, Tanaka K, Ohno S, Egawa N, Yugawa T, Kiyono T. Activation of NF-kappaB by human papillomavirus $16 \mathrm{E} 1$ limits E1-dependent viral replication through degradation of E1. J Virol (2015) 89(9):5040-59. doi:10.1128/ JVI.00389-15

83. Li Y, Wang F, Xu J, Ye F, Shen Y, Zhou J, et al. Progressive miRNA expression profiles in cervical carcinogenesis and identification of HPV related target genes for miR-29. J Patho (2011) 224:484-95. doi:10.1002/path.2873

84. Ding CL, Xu G, Ren H, Zhao LJ, Zhao P, Qi ZT, et al. HCV infection induces the upregulation of miR-221 in NF-kappaB dependent manner. Virus Res (2015) 196:135-9. doi:10.1016/j.virusres.2014.11.023

85. Bouchie A. First microRNA mimic enters clinic. Nat Biotechnol (2013) 31(7):577. doi:10.1038/nbt0713-577

86. Zheng T, Wang J, Chen X, Liu L. Role of microRNA in anticancer drug resistance. Int J Cancer (2010) 126(1):2-10. doi:10.1002/ijc.24782

87. Richmond A, Yang J. The role of NF-kB in modulating antitumor immunity. Oncoimmunology (2015) 5(1):e1005522. doi:10.1080/21624 02X.2015.1005522

88. Kasinski AL, Slack FJ. MicroRNAs en route to the clinic: progress in validating and targeting microRNAs for cancer therapy. Nat Rev Cancer (2011) 11(12):849-64. doi:10.1038/nrc3166

89. Körber MI, Staribacher A, Ratzenböck I, Steger G, Mader RM. NFкBassociated pathways in progression of chemoresistance to 5-fluorouracil in an in vitro model of colonic carcinoma. Anticancer Res (2016) 36:1631-9.

90. Tessitore A, Cicciarelli G, Mastroiaco V, Vecchio FD, Capece D, Verzella D. Therapeutic use of microRNAs in cancer. Anticancer Agents Med Chem (2016) 16:7-19. doi:10.2174/1871520615666150824153358

91. Das KC, White CW. Activation of NF-kappaB by antineoplastic agents. Role of protein kinase C. J Biol Chem (1997) 272(23):14914-20. doi:10.1074/ jbc.272.23.14914

92. Yeh PY, Chuang S-E, Yeh K-H, Song YC, Cheng A-L. Involvement of nuclear transcription factor- $\mathrm{\kappa} \mathrm{B}$ in low-dose doxorubicin-induced drug resistance of cervical carcinoma cells. Biochem Pharmacol (2003) 66(1):25-33. doi:10.1016/s0006-2952(03)00250-8

93. Johnstone RW, Frew AJ, Smyth MJ. The TRAIL apoptotic pathway in cancer onset, progression and therapy. Nat Rev Cancer (2008) 8(10):782-98. doi:10.1038/nrc2465
94. Plantivaux A, Szegezdi E, Samali A, Egan L. Is there a role for nuclear factor kappaB in tumor necrosis factor-related apoptosis-inducing ligand resistance? Ann N Y Acad Sci (2009) 1171:38-49. doi:10.1111/j.1749-6632.2009.04725.x

95. Kumar A, Takada Y, Boriek MA, Aggarwal BB. Nuclear factor-kappaB: its role in health and disease. J Mol Med (2004) 82(7):434-48. doi:10.1007/ s00109-004-0555-y

96. Oyagbemi AA, Saba AB, Azeez OI. Molecular targets of [6]-gingerol: its potential roles in cancer chemoprevention. Biofactors (2010) 36(3):169-78. doi:10.1002/biof.78

97. McClorey G, Wood MJ. An overview of the clinical application of antisense oligonucleotides for RNA-targeting therapies. Curr Opin Pharmacol (2015) 24:52-8. doi:10.1016/j.coph.2015.07.005

98. Tao YJ, Li YJ, Zheng W, Zhao JJ, Guo MM, Zhou Y, et al. Antisense oligonucleotides against microRNA-21 reduced the proliferation and migration of human colon carcinoma cells. Cancer Cell Int (2015) 15:77. doi:10.1186/ s12935-015-0228-7

99. Xiao S, Chen YC, Betenbaugh MJ, Martin SE, Shiloach J. miRNA mimic screen for improved expression of functional neurotensin receptor from HEK 293 cells. Biotechnol Bioeng (2015) 112:1632-43. doi:10.1002/bit.25567

100. Hu N, Zhang J, Cui W, Kong G, Zhang S, Yue L, et al. miR-520b regulates migration of breast cancer cells by targeting hepatitis B X-interacting protein and interleukin-8. J Biol Chem (2011) 286(15):13714-22. doi:10.1074/jbc. M110.204131

101. van Jaarsveld MT, Helleman J, Boersma AW, van Kuijk PF, van Ijcken WF, Despierre E, et al. miR-141 regulates KEAP1 and modulates cisplatin sensitivity in ovarian cancer cells. Oncogene (2013) 32(36):4284-93. doi:10.1038/ onc. 2012.433

102. Brown BD, Naldini L. Exploiting and antagonizing microRNA regulation for therapeutic and experimental applications. Nat Rev Genet (2009) 10(8):578-85. doi:10.1038/nrg2628

103. Nabajit Das NT, Sukant K. Micro RNA mimics and antagonists. Int J Sci Tech Res (2016) 4(12):176-80.

104. Cortez MA, Valdecanas D, Zhang X, Zhan Y, Bhardwaj V, Calin GA, et al. Therapeutic delivery of miR-200c enhances radiosensitivity in lung cancer. Mol Ther (2014) 22(8):1494-503. doi:10.1038/mt.2014.79

105. Wu Y, Crawford M, Mao Y, Lee RJ, Davis IC, Elton TS, et al. Therapeutic delivery of microRNA-29b by cationic lipoplexes for lung cancer. $\mathrm{Mol}$ Ther Nucleic Acids (2013) 2:e84. doi:10.1038/mtna.2013.14

Conflict of Interest Statement: The authors declare that the research was conducted in the absence of any commercial or financial relationships that could be construed as a potential conflict of interest.

Copyright (c) 2018 Wu, Ding, Yang, Guo and Zheng. This is an open-access article distributed under the terms of the Creative Commons Attribution License (CC BY). The use, distribution or reproduction in other forums is permitted, provided the original author(s) and the copyright owner are credited and that the original publication in this journal is cited, in accordance with accepted academic practice. No use, distribution or reproduction is permitted which does not comply with these terms. 